revista ANTHROPOLÓGICAS

Ano 25, 32(2): 9-45, 2021

doi.org/10.51359/2525-5223.2021.249339

\title{
'A Bíblia É o Nosso Regimento': debate parlamentar, liberdade de crença e democracia-liberal representativa
}

Emanuel F. da Silva ${ }^{a}$

Emerson J. S. da Silveira ${ }^{b}$

Resumo: Problematizando a razão de legislar sobre crimes de intolerância religiosa, objetivamos analisar as relações entre religião e política no Brasil contemporâneo a partir dos usos da ideia de liberdade de crença por parlamentares religiosos. A tramitação do Projeto de Lei 578/2019, na Assembleia Legislativa do Ceará, de autoria de deputados do PT e que versava sobre a punição de crimes de intolerância religiosa, foi obstada por deputados evangélicos por enxergarem 'ameaças à Igreja de Jesus', sob o argumento da 'liberdade de crença'. Embasados em metodologias qualitativas - revisão bibliográfica parcial, análise discursiva e dos conceitos 'cidadania religiosa' e 'democracia agonística', investigaremos esta hipótese: os deputados opõem uma 'muralha' contra projetos vistos como 'ameaça à fé', legitimando, nos limites da democracia representativa, o código moral-religioso. Pretende-se compreender, assim, os limites postos à laicidade do Estado pela atuação de parlamentares que fazem da defesa dos interesses de suas instituições a raison d'être de seus mandatos.

Palavras-chave: Representação parlamentar, Liberdade de crença, Intolerância religiosa, Cidadania religiosa.

As porosidades entre religião e política - em disputas eleitorais, formação de governos ou atuação parlamentar - têm sido, pelo menos

a Professor de Teoria Política e dos Programas de Pós-Graduação em Sociologia e em Planejamento e Políticas Públicas (UECE). Email: emanuel.freitas@uece.br.

b Professor do Departamento e do Programa de Pós-Graduação em Ciência da Religião (UFJF). Email: emerson.pesquisa@gmail.com. 
desde os anos de 1980, um tema importante da agenda de pesquisas, seja da Ciência Política, da Sociologia ou de outras Ciências no campo das Humanidades.

Nos limites da democracia representativa, essas porosidades permaneceram compreendidas sob a chave da categoria 'adversário', presente na política liberal, amplamente hegemônica dentro das democracias liberais representativas no mundo ocidental (Mouffe 1993, 1999 e 2000). Podemos dizer que a hegemonia do modelo econômico capitalista liberal, em especial no Pós-Segunda Guerra, colaborou para criar um horizonte de imaginação política na qual o poder do EstadoNação era e ainda é disputado como um mercado no qual os partidos políticos e seus agentes se alternam, concordam com um ideário de tolerância geral e religiosa, concorrem e disputam poder, redistribuído posteriormente ${ }^{1}$. Todavia, podemos também pensar na tradição agonística da democracia, de modo paralelo à tradição liberal e dentro da qual a política é compreendida como uma disputa - podendo, por vezes, tomar a forma discursiva de uma 'guerra' (violenta e cruenta), com uma atuação imaginada como 'batalha', em que os partidos e seus agentes se tratam como se estivessem em meio a uma trincheira e se imaginam em uma trama agonística (Mouffe 2013).

A religião - em algumas de suas expressões, as mais reacionáriasconservadoras e individualistas, tornou-se, de algum modo, uma caixa de ressonância dessa antiga tradição agonística nos regimes de democracia representativa. Com a formação do Estado Laico, em especial no Brasil, os atores religiosos puderam constituir dentro dos partidos uma voz institucionalizada que vai ao Parlamento e, de lá, pauta uma trincheira de combates. No Brasil, desde o século XIX e começo do $\mathrm{XX}$, os evangélicos (distribuídos em grupos históricos, de imigração e missão e os pentecostais), que eram minoria religiosa, cultivaram diversas vertentes de expressão teológico-política, do apoliticismo, temperado pelo milenarismo - no aguardo da Parusia, o retorno do Cristo e inauguração de seu reino - aos messianismos ativistas de matizes mais pacifista-místico ou de combate-bélico. 
A partir dos anos 1980 esses grupos, uma vez eleitos, passaram a vocalizar uma posição de enfrentamento e belicosidade contra outros grupos sociais, em especial os liberais de centro e as diversas matizes da esquerda. Retira-se a perspectiva liberal-representativa de cena e recoloca-se a perspectiva agônica-inimical. Não vamos nos deter nas razões que possibilitaram isso, mas vamos nos ater aos usos do termo e a definição de 'liberdade religiosa' por parte de parlamentares religiosos.

Nesse sentido, a discussão em torno da tramitação de um projeto de lei na Assembleia Legislativa do Estado do Ceará (ALCE), de autoria dos quatro deputados do Partido dos Trabalhadores (PT) que exercem mandato na Casa, levada a cabo por dois deputados evangélicos, Silvana Pereira (Partido Liberal - PL) e Apóstolo Luiz Henrique (Partido Progressista - PP), é paradigmático da ampla crise do pacto civilizatório da Modernidade. O referido projeto, e os inflamados debates em torno de suas implicações, servirão como corpus de análise de nossa discussão, que objetiva responder à seguinte questão: que usos da ideia de liberdade religiosa são feitos por parlamentares religiosos e que lugar tais usos conferem a religiões minoritárias?

A motivação para a escrita deste artigo, dentro de uma agenda de pesquisa desenvolvida pelos autores em torno da atuação parlamentar de religiosos, se deveu ao fato de os referidos atores do campo político institucional que se opunham ao Projeto de Lei, referirem-se ao mesmo pontuando explicitamente o fato de, na justificativa dele, haver uma referência às 'religiões de matriz africana' e de ressaltarem os 'prejuízos' que a aprovação de um tal projeto poderia trazer 'à Igreja do Senhor Jesus'. Analisando a argumentação presente em seus discursos, bem como a contra-argumentação e defesa do projeto por parte de um de seus autores, Elmano de Freitas (PT), ver-se-ão os limites impostos à ideia de 'liberdade de crença' no atual cenário político-religioso do país, engendrando uma cada vez mais acentuada busca por representação religiosa da parte de religiosos sob a crença de uma 'ameaça à cristandade' em curso, que 
legitimaria tal representação, operando, esta, para a construção de uma proteção legal ao cristianismo, religião hegemônica entre os brasileiros.

O debate em torno do Projeto mobilizou parlamentares tanto da Assembleia Legislativa do Ceará (ALEC) como da Câmara Municipal de Fortaleza, evangélicos e católicos carismáticos, numa espécie de 'cruzada' contra um projeto que visaria processar religiosos por 'defender a religião' ${ }^{2}$, e serviu como importante incremento na oposição de religiosos à esquerda partidária, uma vez que o projeto fora apresentado por parlamentares do PT, engendrando uma intensa campanha contra ele nas redes sociais, na imprensa e nos Plenários das duas Casas.

O texto está estruturado da seguinte forma: inicialmente, uma discussão em torno da literatura sobre a representação política (a que nos pareceu mais afim à discussão que aqui elaboramos); após isso, uma apresentação geral da participação eleitoral de evangélicos no Brasil contemporâneo, destacando análises produzidas acerca desta participação, nos permitindo compreendê-los como importantes 'atores políticos'; ao fim, uma apresentação/discussão do debate ocorrido na ALCE em torno do projeto.

As particularidades das relações entre esses dois campos, religião e política, que pareciam autonomizados por consequência dos diversos processos de modernização pelos quais as organizações nacionais haviam passado, têm alterado a estrutura de funcionamento destes, nos permitindo considerar, com outros tantos pesquisadores, relações de continuidade no cotidiano da política e da religião a partir da atuação dos atores de ambos os campos, alterando mesmo um conjunto de repertórios de ação no interior dos espaços (políticos e religiosos), com destaque para a linguagem, que se desloca de um campo a outro.

Baseados em metodologias qualitativas - revisão bibliográfica parcial, análise discursiva e conceituação, sobretudo pensando a partir das categorias de 'cidadania religiosa' (Vaggione 2017) e 'democracia 
agonística' (Mouffe 2000, 2013) - investigaremos a hipótese de que os religiosos deputados, dentro dos limites da democracia representativa, estabelecem uma hermenêutica restrita do código moral-religioso ('a Bíblia é nosso regimento') e se colocam como uma 'muralha e um exército' contra projetos compreendidos como 'ameaça à fé'. A guerra teológico-política explicita os impasses da democracia brasileira vivida mais como moldura e solvente da atuação destes políticos do que como ambiente cultural-social impregnante da vida cotidiana.

\section{Questões em torno da representação política}

A representação política tem sido considerada um dos elementos constituintes das modernas democracias, de tal modo que falar de governo democrático tem sido compreendido como falar em representação. $\mathrm{O}$ poder legítimo tem sido definido pela presença da representação em seu interior. Desde a questão formulada por Pitkin (1967), a representação política é pensada a partir da possibilidade de os representantes agirem de forma a guardar uma relação o mais estreita possível com os interesses dos representados, servindo o Parlamento como o locus por excelência desta relação de proximidade, identificação e controle.

Assim, pensar em representação é encontrar respostas para a questão do 'quem representa', 'a quem representa' e 'como representa'; e tais respostas tratam da legitimidade eleitoral a partir da qual indivíduos agem em nome de outros indivíduos ou de coletividades (mobilizando discursos que, de outro modo, não teriam como ser mobilizados, buscando reconhecimento de um certo público), produzindo a expressão material de escolhas de interesses e preferências eleitoralmente conquistadas. Exatamente por isso é que "a representação política é um processo que permite o social se tornar político"3 (Almeida 2013:48).

A representação, pois, requer a escolha de alguns indivíduos por outros, escolha esta produzida pela possibilidade (tida como real) de terem seus interesses contemplados pela ação daqueles que os represen- 
tarão, isso possibilitado pela coincidência de interesses entre políticos e cidadãos. Como nos lembram Manin, Przerworski \& Stokes, "para serem eleitos os políticos podem ter que fazer promessas a interesses específicos" (2006:112), isto é, não falar à totalidade dos eleitores mas àqueles identificados com os mesmos interesses. Isso permitiria, pois, um discurso lançado a um "eleitor decisivo" (Manin, Przerworski \& Stokes 2006:114), que tendo seus interesses contemplados, serviria como um seguro 'investimento' quando a possibilidade de reeleição se avizinhasse. Os autores pensam a representação tanto sob a ótica do mandato, no sentido de acolhimento da demanda por incorporação do interesse, como sob a ótica da prestação de contas, mecanismo pelo qual o representante preservaria suas posições na mais estreita relação possível com os representados. Quanto mais completas forem as informações que estes têm da atuação daqueles, mais esse mecanismo é exitoso. Daí, pensamos que a representação religiosa parece-nos ser mais próxima da possibilidade de realização desse controle por parte dos representados, pois o desempenho dos representantes, e sua devida publicização, torna-se o mecanismo por excelência de informação para o público.

Nadia Urbinati (2006) considera a representação política como um processo de 'disseminação da presença do soberano' pelo corpo social, permitindo uma busca contínua pela legitimidade da fala e da ação de representantes que precisarão recriar os modos de relacionarse com a sociedade representada. Para tanto, entram em cena os mecanismos da opinião e do juízo, próprios de regimes democráticos, em torno daqueles que exerceriam com satisfação a representatividade e a defesa dos interesses dos sujeitos.

A representação parlamentar, assim, traduz condições e interesses em matérias legislativas que, junto a outros interesses, atravessam uma arena de lutas para a transformação de interesses em legislação. Representar é agir no interesse do representado, tornando seus interesses matéria legislativa, agindo responsivamente. Isso porque é no plano das ideias e crenças, e da devida resposta a elas, que se pode compre- 
ender, segundo a autora, a representação, que é produzida pelo voto, ato definido como "uma tentativa de se dar peso às ideias", pois "traduzimos ideias em votos" (Urbinati 2006:211).

Pensamento semelhante tem Young (2006) ao elencar crenças, opiniões e perspectivas sociais como imprescindíveis à compreensão da noção de representação política, todas elas relacionadas aos modos de se olhar o mundo, e de se representar o mundo, inclusive na escolha daqueles que legitimarão tal modo no exercício de mandato. Em sua definição,

"A representação consiste num relacionamento mediado entre membros de um eleitorado, entre este e o representante e entre os representantes num organismo de tomadas de decisões. Na qualidade de um relacionamento prolongado entre os eleitores e seus agentes, a representação oscila entre momentos de autorização e de prestação de contas" (Young 2006:151).

Como um relacionamento dual, a representação se dá entre agentes de decisões e eleitorado; este enxerga naqueles, os modos mais efetivos de expressão de suas demandas. É em torno da tomada de decisões que a representação deve ser compreendida, uma vez que tais decisões possibilitam observar o grau de conexão entre as duas partes do mecanismo representativo.

Mobilizando as categorias 'interesses', 'opiniões' e 'perspectivas' a autora apresenta sua compreensão do que entende pelo sentimento de 'sentir-se representado' no processo político por parte do eleitorado, pois é por meio delas que este enxerga o que pensa dever ser "as prioridades" que norteiam "as decisões políticas" e são "verbalizadas" em "discussões deliberativas" (Young 2006:158). Essas questões nos possibilitam pensar os modos como a representação política tem sido acionada como mecanismo importante de legitimação de interesses de evangélicos dentro do jogo institucional, e mais ainda dentro das dinâmicas demográficas e sociais a partir da nova configuração da sociedade brasileira. À medida em que os anos passam, vão ficando mais claras suas estratégias, cada vez mais exitosas, de verem-se como 
legítimos atores do campo político brasileiro, atuando como verdadeiros players, pondo em ação mecanismos identificados por esses teóricos como próprios dos atos de representação, com destaque para a representação de crenças, opiniões e perspectivas, como veremos mais adiante.

\section{Participação eleitoral e política de evangélicos no Brasil contemporâneo}

Os estudos sobre a participação dos evangélicos na esfera política acompanham os processos de redesenho do poder político no Brasil. Oro (1996) nota que a presença dos evangélicos na política nacional, até 1945, era reduzida e se dava em torno de iniciativas individuais. Em termos gerais, os evangélicos não eram mais que 3\% da população brasileira.

No período getulista, tanto o revolucionário quando a ditadura do Estado-Novo (1930-1937; 1937-1945), em meio à tentativa de recatolização da sociedade empreendida pela Igreja, os evangélicos organizaram-se e elegeram um deputado federal (Guaracy Silveira) que, naquela época, confeccionou documentos defendendo a liberdade de culto e expressão, além de tratamento igualitário entre as religiões (Freston 1993). Havia também, um pequeno, mas consistente, espaço para a retórica do combate ao inimigo - sempre ambíguo e nebuloso, ora o comunismo, ora a imoralidade - que estava mais dentro dos púlpitos dos templos, onde se mesclavam as questões morais-teológicas (a corrupção da sociedade sob o domínio do mal) e as políticas propriamente ditas (eleger representantes cristãos).

Entre 1951 e 1987, o número de protestantes eleitos esteve entre 6 e 12 deputados (Freston 1993:3-105). Nesse período os evangélicos passaram a ser algo em torno de $10 \%$ da população. A campanha pelas 'Diretas-Já' (1984-1985), cujo objetivo central era apressar o fim da Ditadura Militar (1964-1985), teve como uma de suas consequências a mobilização de forças de esquerda(anarquistas, libertárias), movimentos sociais, sindicais e religiosos (Teologia da Libertação no 
campo católico e protestante) e fez avançar a discussão de pautas mais liberais, como a descriminalização do aborto e das drogas, fome, reforma agrária, direitos reprodutivos das mulheres, racismo, feminismo e outras pautas econômicas e políticas (economia solidária, democracia social-participativa ou democracia de base). Houve reação em setores evangélicos e, quando a Assembleia Nacional Constituinte foi convocada pelo presidente José Sarney, uma ininterrupta organização da nascente bancada evangélica, lastreada na ideia de representação liberal democrática (representante/representado), tomou a forma de um coletivo organizado para a defesa dos interesses do grupo, mas com uma leitura singular do que estaria em questão no jogo político: o corpo da nação brasileira seria cristão, portanto, o Estado deveria acolher a vontade geral da maioria do corpora sacris.

Pierucci (1989), ao abordar a atuação da 'Bancada de Deus' no processo de convocação e elaboração da Assembleia Nacional Constituinte de 1986 e o respectivo Congresso, aponta números tímidos daquela primeira empreitada política: apenas 33 parlamentares, dos quais 18 eram pentecostais (Assembleia de Deus, principalmente). Chamava-se atenção para traços da luta evangélica no espaço laico -público, amparado pela relação entre eleição e representantes: uma mescla entre pautas corporativas (canais de TV/Rádio, apoio estatal a entidades paraeclesiais, como as comunidades terapêuticas etc.) e pautas morais-conservadoras (combate ao aborto, relativização dos direitos humanos). Uma pauta saudosa de tempos idealizados em que a religião, ou um tipo dela, sacraliza, naturaliza e hierarquiza a vida, a família, o casamento, a sexualidade, a liberdade individual. Fonseca (2002) lembra que a maioria dos parlamentares vinculados à bancada evangélica atuaria dentro e à direita do bloco de poder chamado de 'Centrão', grupo político eclético, composto por herdeiros da Ditadura Militar (Arena, PFL), da direita ideológica e da direita fisiológica, compostas por políticos afeitos a barganhas.

A partir dos anos 1990, o boom pentecostal e neopentecostal passou a hegemonizar o campo evangélico. São os anos de emergência 
e consolidação do neopentecostalismo (tendo a Igreja Universal do Reino de Deus como paradigma), que operam três reatualizações do multissecular imaginário de liberdade de crença e de perseguição: a) a guerra espiritual total contra as malversações do diabo no corpo e na alma dos crentes (o exorcismo intolerante que dá conta das doenças; no espaço público, a guerrilha de ocupação total de órgãos, como conselhos tutelares e câmaras municipais, estaduais e federal); b) a teologia da prosperidade, afinada com os liberalismos e neoliberalismo econômicos, exaltando a capacidade do indivíduo com fé em Jesus (liberdade de crer), ter prosperidade ao cumprir ações rituais e lutas, se auto-imaginando como impedido por forças demoníacas (perseguição religiosa); c) a confissão positiva (pensamento e ato mágico de afirmação absoluta e soberana da vontade individual de alguém que, ao crer e invocar Deus, terá tudo resolvido, de suas dívidas e desemprego à imunidade a doenças). Daí ocorrerá, segundo Siuda-Ambroziak (2017), o processo de neopentecostalização da política brasileira, posteriormente sucedido por um outro, o de pentecostalização (Burity 1997).

O crescimento da população que se confessava evangélica nas várias correntes do segmento acelerou-se, bem como a eleição de parlamentares nas três esferas de poder, num longo processo de capilarização (Quadros \& Maderia 2018). Em 2003 é criada oficialmente a Frente Parlamentar Evangélica (FPE) e desde essa data cresce exponencialmente, não obstante uma pequena redução em 2006, ano de inflexões políticas e econômicas no Brasil, com o reforço da aproximação do Governo Federal com as igrejas pentecostais e neopentecostais e os desdobramentos das crises entre 2014-2018 (crise econômica, impeachment de Dilma, eleição de Bolsonaro).

Quadro 1 - Bancada Evangélica no Congresso Nacional (deputados e senadores)

\begin{tabular}{|c|c|c|c|c|c|c|}
\hline Ano & 2002 & 2006 & 2010 & 2014 & 2018 & 2020 \\
\hline Quantidade & 60 & 29 & 42 & 77 & 91 & 120 \\
\hline
\end{tabular}

Fonte: Pesquisa dos Autores, 2021. 
Com o passar do tempo, esses grupos cresceram, mudaram a retórica, pari passu às crises de governabilidade e do sistema de representação política no Brasil, acopladas às crises econômicas, e introduziram uma 'pedra de tropeço' - imagem bíblica recorrente nas falas religiosas - no atual modelo liberal-laico brasileiro de poder parlamentar. Sob os governos de esquerda, a bancada evangélica registrou o maior crescimento, enquanto sua retórica fortalecia a polaridade belicista.

Quadros e Madeira (2018) realizaram um estudo importante sobre que tipos de categorias discursivas são mobilizadas nos discursos desses políticos religiosos no Plenário do Congresso Nacional. A ascensão da ideia de enfrentamento direto, guerra espiritual, luta contra as forças do mal, dentre outras, é considerável, trazendo fissuras à imagem tradição conciliadora-consensualista da democracia liberal-representativa brasileira.

Quadro 2 - Categoria 'ataque à esquerda' - deputados em plenário federal (2010-2017)

\begin{tabular}{|c|c|c|c|c|c|c|c|c|}
\hline Ano & 2010 & 2011 & 2012 & 2013 & 2014 & 2015 & 2016 & 2017 \\
\hline Quantidade & 30 & 9 & 9 & 25 & 22 & 48 & 67 & 151 \\
\hline
\end{tabular}

Fonte: Quadros \& Madeira (2018). Adaptado.

A ruptura introduzida pelo modo evangélico de produzir dissensos pode ser posta em contraste com o modelo anterior de pactuação entre política, Estado e religião, construído após a Proclamação da República. Depois de um período conflituoso, a Igreja Católica vertebrou, junto com o aparato republicano, o esqueleto institucional desse acordo e a cultura católica o encheu com elementos culturais. Esse modelo, analisado por Paula Montero (2009), deu fôrma e código para todas as expressões religiosas no espaço público e político. Estas, de algum modo, lançaram mão desse modelo católico para se fazerem respeitadas a partir da primeira constituição republicana, com mais sucesso, no caso do kardecismo, ou com mais dificuldade, no caso das 
tradições afro-brasileiras (umbanda e candomblé), objeto de histórica perseguição e censura. $\mathrm{O}$ que caracteriza esse modelo ou gramática católica são três aspectos: o conflito, a retórica agônica e a figurado inimigo são subsumidas pela produção de consensos e acordos possíveis nas mediações da democracia representativa. Nessa concertação, o Estado concede às expressões religiosas institucionalizadas, um papel e uma função complementária (serviço social, educação, saúde) e elas dão uma parte da legitimidade social de que carecem os governos civis. A concertação católico-consensual fragilizou a laicidade a abriu fendas nunca mais fechadas, mas bem aproveitadas pelos evangélicos reacionários no bojo de um processo de reconfiguração institucional e cultural da relação entre religião, Estado e política. Resta saber se essa nova gramática evangélica, diversa da católica que regeu a República enquanto o catolicismo e a Igreja eram quase monopólios, também inspira, e de que modo inspira, expressões religiosas na forma como se relacionam com o Estado e a política. Uma hipótese que podemos lançar a essa questão: a gramática agônico-evangélica fornece fôrma e código semântico para muitas expressões religiosas, inclusive, movimentos católicos, como os reacionários e ultraconservadores (Opus Dei, Arautos do Evangelho, TFP, RCC).

Os grupos religiosos mais bélicos, os que tinham retórica de enfrentamento radical, calcados em míticas imagens bíblicas da perda da virtude geral das sociedades e da vontade de Deus de restabelecê-las por meio de seus guerreiros-representantes, formavam o que no imaginário evangélico veio a se chamar de Gideões. Aqui, temos referência ao relato que mistura história e mito, de um pequeno exército de trezentos guerreiros, liderado por Gideão, que guerreou e venceu os povos cananeus, em especial os midianitas (Juízes, capítulos 7 e 9, 2009, Bíblia, Versão Almeida Fiel). ${ }^{4}$

A presença desse termo nos argumentos esgrimidos contra projetos de lei, como o da ALCE por parlamentares evangélicos - auto atribuindo-se a ideia de representante-mór do cristianismo puro e real, o que não é verdade de fato ${ }^{5}$ - maneja simultaneamente a ideia de 
minoria e tolerância religiosa, da tradição liberal e, também, a retórica de combate belicista, persecutória, advinda da tradição antiga medieval. Dizem algo como "estamos apenas reagindo a uma guerra movida contra nós”. Assim fazendo, acionam a vertente veterotestamentária bélica e, por meio do recurso à ideia do inimigo, escancaram os limites do atual modelo democrático-representativo liberal no arcabouço da laicidade estatal brasileira. O pacto de separação Igreja-Estado, parcial e submetido a controvérsias no Brasil, é acossado por esses agrupamentos religiosos, e é 'estremecido' (Mariano 2011). Esse pacto social é baseado no contrato social moderno, em um modelo de relação entre representante e representante, entre Religião e Estado que foi colocado contra a parede pela ascensão dos populismos de direita aliados, indissoluvelmente ao que parece, aos grupos religiosos cristãos reacionários-conservadores em guerra pelo que consideram a eternidade. Em outras palavras, buscam o tempo mítico em que as hierarquias sagradas (um único modelo de família, de nação, de mercado, de Estado etc.) está sob a luz de um Cristo Pantokrátor, rei de tudo e de todos, a quem devem vassalagem e obediência estrita, sob pena de expulsão do paraíso.

É forçoso dizer que, uma vez que a tradição agnóstica de política entra em cena, e no caso, por parlamentares evangélicos, tudo se torna palco de operações bélicas: as ações desses grupos conservadores-reacionários, embora se vejam como revolucionários contra um suposto establishment, e as reações e ações políticas dos demais grupos, religiosos-políticos ou político-laicos, vistas como ataque, guerra de perseguição, inspirada não raro, pelo inimigo maior, Satanás, Diabo ou Demônio, segundo a ótica religioso-moral.

Um elemento que podemos notar entre os estudos dos últimos anos, sejam antropológico-etnográficos (Almeida 2019; Machado 2017; 2014; Cunha 2015) ou macrossociológicos e histórico-sócio-políticos (Burity \& Machado 2006; Almeida 2017; Mezzomo, Silva \& Pátaro 2021) e a forte presença da nebulosa metafora da guerra espiritual conjugada à ideia de perseguição e força individual: soldados 
de Cristo, estratégia do Diabo, batalha de alma, luta ou guerra contra inimigos/Inimigo (marxismo cultural, Covid-19, imoralidade, pedofilia, comunismo, corrupção, 'kit gay'), batalha pela família e batalha dos justos contra os ímpios.

Não importa se são inimigos inventados, como peças heteróclitas e sem senso de veracidade nenhum, se são inimigos com algum grau de veracidade: todos estão sob uma outra guerra, espiritual, na qual a batalha é pela alma da nação, do povo, de cada pessoa e na qual vale a pena ser o guerreiro de Gideão.

E aqui é preciso notar que, se vermos o momento epocal em que vivemos, sob olhares mais longo e meta-empíricos - veremos a acuidade da observação de Ludwig Wittgenstein (2005) sobre a estrutura fundamental da linguagem. Esta é pragmática, gira em falso: não há ligação ontológica e causal entre a coisa (o representado) e o nome ou a palavra (o representante). O sentido da linguagem é definido pelas múltiplas práticas sociais, mas que estão submetidas às pressões estruturais socioeconômicas, políticas e religiosas, ao campo de atores, instituições e agentes que disputam a hegemonia da semântica. Por si, esses fatores perturbam a lógica racional da relação representante-representado nos modernos regimes democráticos, mas, havia uma razoável produção de consenso social que estabilizava o sentido e produzia uma 'naturalidade' do sistema representativo-liberal democrático.

Mas, a partir da ascensão das redes sociais, das plataformas e aplicativos digitais, do capitalismo financeiro desregulado e global e da cultura neoliberal - ênfase na ideologia da meritocracia, do empreendedor e do indivíduo vencedor - assistimos a invasão da pós-verdade no território da democracia liberal-representativa (Bucci 2019). A pósverdade é a tradução, em termos sociais, de uma época em que não importam mais os critérios de verdade e falsidade que caracterizavam a modernidade, para reger, balizar, regrar e balancear o pacto civilizatório e político (democracia liberal-representativa) e o contrato da laicidade estatal. 
Notamos aí uma ligação com a ideia de giro em falso da linguagem ou de símbolos que representam a si próprios (Wagner 2017). Nossa época de redes sociais, virtualização de reações sociais e espetacularização do narcisismo, escancara o fosso semântico entre representados (coisas, povo, grupo, nação) e representantes (palavras, políticos, eleições). O mais importante passa a ser o absurdo, o exótico, o abstruso de imagens, falas e posts, que mobilizam bolhas nas redes sociais, com marketing e consumo, nas quais se engajam, não apenas os grupos religiosos conservadores-reacionários, mas os grupos sociais como um todo. A imagem 02, exibida mais adiante, mostra, simultaneamente, a convergência entre a retórica do inimigo, o tópico histórico da liberdade de crença e da perseguição religiosa e a necessidade de espetacularização das redes sociais, (dis)torcendo sentidos e os submetendo à comandos outros: o interesse da bancada religiosa em ser representante do Cristo Pantokrátor, que vem dominar o mundo em fogo, fúria e glória (uma visão estereotipada e idílica presente em muitos grupos evangélicos). A nova arquitetura das relações sociais em geral, e das relação entre eleitos e eleitores ou representantes e representados, movidas a likes, compartilhamentos e comentários infindos, torna a retórica de guerra e do inimigo, e do favorecimento do direito de não-tolerar, empunhado pelos grupos evangélicos, ainda mais estranha na velha sinfonia que a partitura representativo-liberal da democracia propõe, com suas ideias de tolerância e direitos formais, muito antenadas com o antigo pacto civilizatório, alinhado às ideias de concorrência e adversário, de ciência, reflexividade e verificação da verdade a partir de critérios autônomos em relação ao aplauso ou ao valor de espetáculo

\section{'Eu só faço o que Jesus manda': o debate parlamentar em torno da liberdade religiosa}

Neste tópico pretendemos apresentar nossa análise daquilo foi o debate parlamentar em torno da liberdade religiosa a partir da discus- 
são, e arquivamento, de um projeto de lei que versava sobre punição a atos de discriminação por motivo religioso.

$\mathrm{Na}$ atual legislatura, de um total de quarenta e seis, a ALCE conta com três parlamentares, que se apresentam como evangélicos: Silvana Pereira (PL), Apostolo Luiz Henrique (PP) e David Durand (Republicanos). A primeira é da Assembleia de Deus, o segundo é fundador e líder da Igreja do Senhor Jesus e o terceiro é da Igreja Universal do Reino de Deus. Além destes, Walter Cavalcante $(\mathrm{MDB})$, que é católico, também se apresenta a partir da marca religiosa. Outros parlamentares costumam acompanhar as indicações de votação dos deputados evangélicos em matérias que são do interesse destes. Vejamos a seguir os fatos em torno do projeto apresentado.

\section{. O texto do Projeto}

Em 21 de outubro de 2019 os quatro deputados do PT ${ }^{6}$ com assento na ALCE protocolaram o pedido de tramitação do Projeto de Lei 578/20197, que versava sobre "penalidades administrativas a serem aplicadas pela prática de atos de discriminação por motivo religioso”. A justificativa para o projeto citava casos de intolerância praticados no Brasil "com a chegada dos portugueses" e destacava textualmente a "perseguição por senhores e pelo clero" a "negros e indígenas" que, para fugirem desta, acabaram por produzir "o sincretismo", "cultuando os seus orixás" através dos santos católicos. Além disso, citava ainda casos de perseguição religiosa em alguns países (China, Paquistão e Arábia Saudita) e apresentava o Brasil como um país constitucionalmente laico.

Por laicismo, o texto do projeto entendia a não-interferência da religião nos assuntos de Estado, dizendo ser também função de um estado laico o não-apoio e a não-discriminação a nenhuma religião, "adotando uma posição neutra no âmbito religioso". A leitura do texto expõe uma série de fragilidades, do ponto de vista sociológico, mas 
que não nos cabe aqui analisar. Os atos considerados como discriminatórios eram os seguintes:

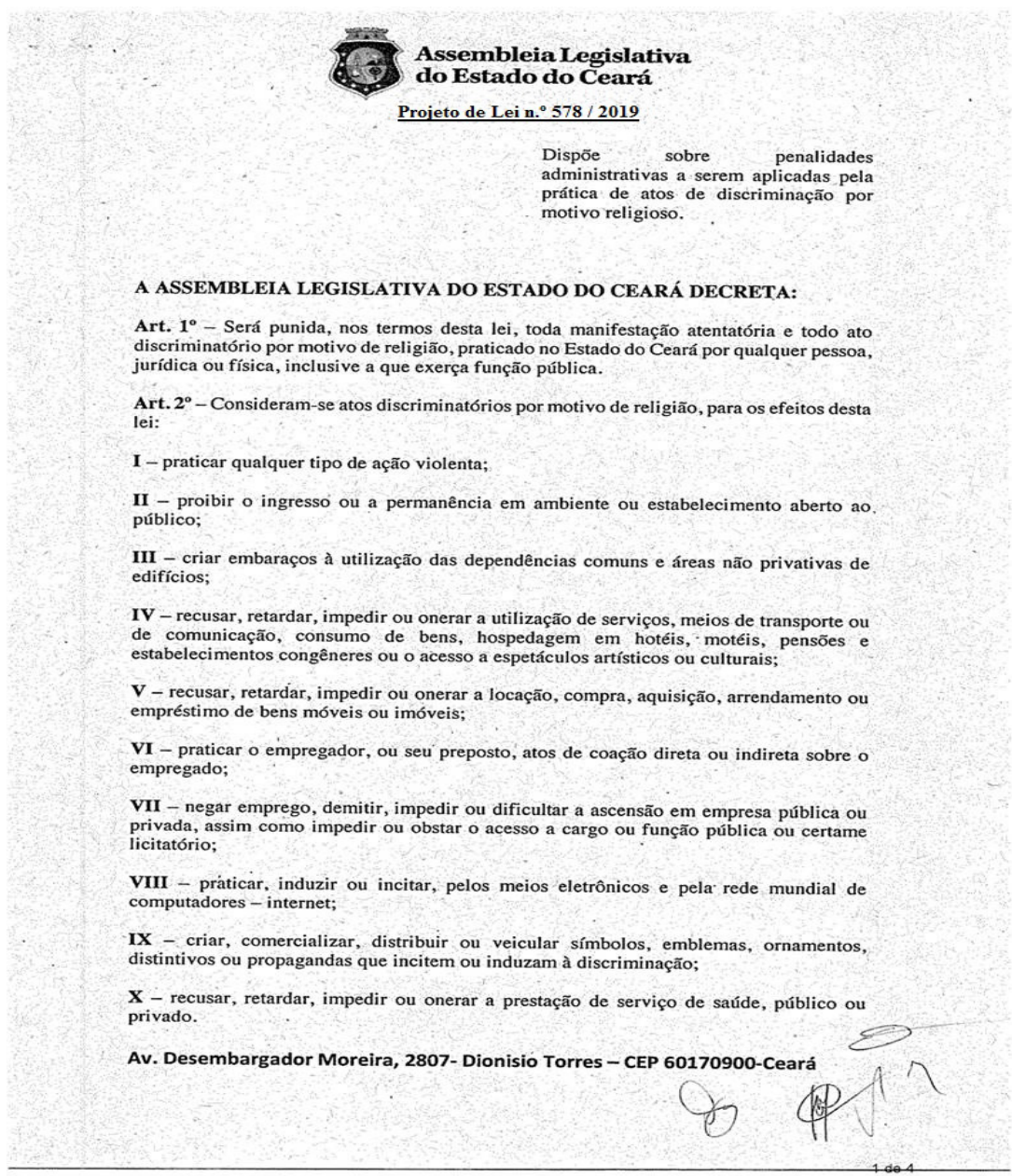

Imagem - 1: Projeto de Lei.

Naquele mesmo dia se iniciaria uma mobilização, via redes sociais, contra o projeto, desde sempre compreendido como um projeto 
de lei que 'ameaçava a fé cristã'. Em suas redes sociais, a deputada Silvana Pereira assim se expressou:

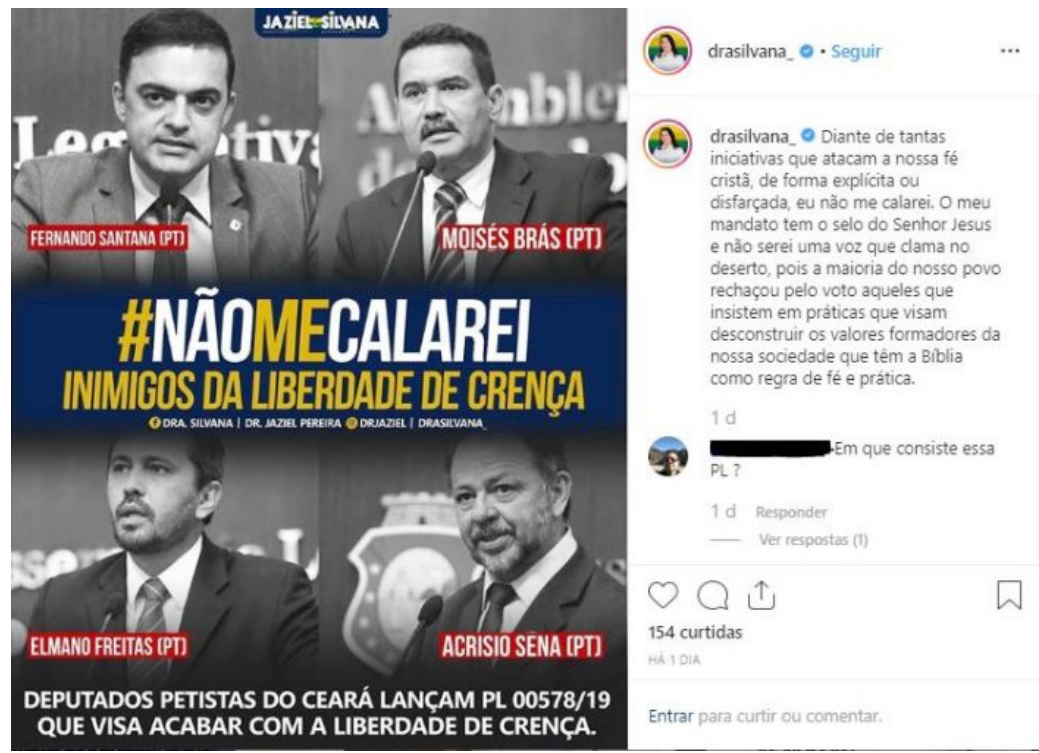

Imagem - 2: Post em rede social.

Fonte: Conta no Instagram de Silvana Pereira

Também por suas redes sociais, a vereadora Priscila Costa (então no PRTB, hoje no PSC), evangélica da Assembleia de Deus, expressou-se mobilizando seus seguidores contra o projeto, destacando-o como de autoria de deputados do PT. A vereadora, que se apresenta em suas redes sociais como anti-feminista e conservadora, tem se notabilizado, na cidade de Fortaleza como uma 'valorosa combatente' em nome dos 'valores cristãos'; exatamente por isso, legitimou-se, nos últimos dois anos, dentro do campo religioso nacional, participando como convidada de inúmeros eventos, como o Simpósio Nacional de Direito Religioso, em 2020, na condição de palestrante, e no Encontro da Frente Nacional contra Ideologia de Gênero, também naquele ano. Sobre o projeto aqui em questão, fez a seguinte postagem: 


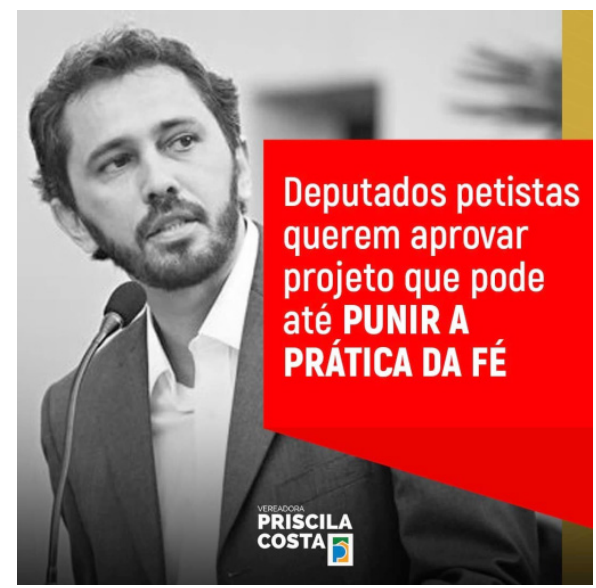

Imagem - 3: Post em rede social.

Fonte: Conta no Instagram de Priscila Costa

Mais enfático ainda foi o discurso proferido na Câmara Municipal pelo vereador Jorge Pinheiro (então na DC, hoje no PSDB), que é membro da Renovação Carismática Católica, consagrado na Comunidade Shalom. Ele assim se expressou, dando um sentido de impedimento de pregação do cristianismo a ser exercido com a possível aprovação do projeto:

Estão querendo nos amordaçar na luta pelas nossas crianças e pelo direito de propagar o Cristianismo. Quer dizer então que esta minha fala poderia ser processada porque defendo minha religião? [...] Parece aquela história da cruz suástica. É não! Sabem o que estão fazendo, dizendo que é indução à discriminação? Estão pedindo para retirar os crucifixos dos estabelecimentos públicos [...] Isso fere nosso direito de crença, de religião, isso não é defesa de Estado laico, é antirreligioso ${ }^{8}$.

\section{. O debate na ALCE - o 'interesse da Igreja’ está acima do direito constitucional?}

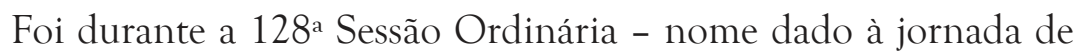
trabalho parlamentar dentro do período regular do ano legislativo - 
realizada em 23 de outubro de 2019, que o projeto de lei entrou em discussão, após a mobilização via redes sociais e bastidores tanto da parte de vereadores como dos deputados e dos líderes religiosos que os acompanhavam.

A primeira a discursar, na condição de primeira orada inscrita para aquele dia, foi exatamente Silvana Pereira. Dirigindo-se de início ao deputado Elmano, um dos autores do projeto, e referindo-se a si e ao deputado Apóstolo Luiz Henrique como parlamentares que estavam na ALCE 'para combater', a deputada solicitou que o deputado retirasse o projeto de tramitação, não sem antes relatar a motivação e o auxílio que tivera para opor-se ao mesmo:

E falei agora com o Pastor Salomão e disse: "Pastor Salomão, como é que eu consigo, como é que eu começo, como é que eu início esse discurso que para mim é difícil quando é um projeto de um colega parlamentar, de um amigo parlamentar, agora de quatro amigos, como é que eu começo Pastor Salomão para poder ter coragem de iniciar o meu estilo profético de discurso, sem ferir, sem ofender?" Ele me orientou da seguinte forma, Apóstolo Luiz Henrique: "querida suba a Tribuna e diga que esse projeto é inegociável. Diga e peça na Casa Legislativa para os quatro deputados do PT, diga que a Igreja do Senhor Jesus se sente ofendida"; "diga que a Igreja do Senhor Jesus se sente tolhida; diga que a Igreja do Senhor Jesus não aceita esse projeto a ponto de, se a insistência até na tramitação dele, nós entraremos no Ministério Público, nós os pastores, nós a Igreja do Senhor Jesus". Ele disse, inclusive: "nós nos manifestaremos em grandes multidões”. (Silvana Pereira).

Em seu 'discurso profético', e não 'parlamentar', a deputada dava mostras a seu colega de Casa que o projeto de sua autoria, sua tramitação e possível aprovação era 'inegociável', pois "a Igreja se sente ofendida”. A deputada assumia, ali, ser representante da 'Igreja', o que significa dizer, antes de tudo, dos 'pastores' que a orientaram, uma vez que ela mesma diz terem sido estes a darem a tônica, e as razões, de seu discurso. O objetivo é, antes de tudo, alertar ao deputado acerca da possibilidade de ver contra si 'grandes multidões', lideradas, ao certo, pelos mesmos pastores que haviam preparado, ou 'ungido', a 
parlamentar momentos antes de subir à tribuna, na condição de evangélica-deputada. A imagem do encontro preparatório foi divulgada na imprensa cearense, como podemos ver abaixo:

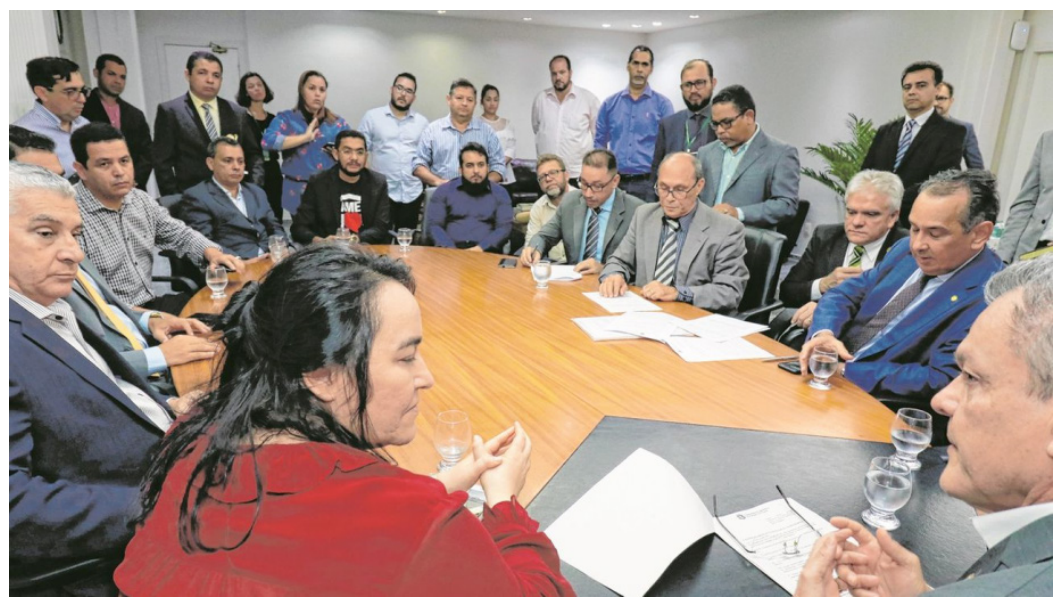

Imagem - 4: Deputada Silvana e pastores na ALCE.

Fonte: Diário do Nordeste, 29/10/2019.

Num discurso em tom emotivo, que lembrou a histórica perseguição à igreja protestante no Brasil (discurso para o qual trouxe supostas passagens de sua biografia, com destaque para a mãe, que, segundo disse, cantarolava hinos evangélicos em tom tal que chegava ao vizinho "adepto de religiões afro", convertendo-o), a deputada defende o que chama de "preconceito religioso", artifício por meio do qual evangélicos diriam que "contra o que outras pessoas acreditam ser correto, que nós entendemos que leva para o inferno, que é maldição, que é ilícito", seja o que for (no plano dos costumes ou das práticas religiosas), e que consistira na "liberdade de falar, que o Estado laico nos traz". Será, pois, em nome de tal liberdade de falar (leia-se: liberdade de condenar e exasperar algumas coisas, práticas e pessoas que não condizem com seu credo) que a deputada defenderá a retirada do 
projeto, dando mostras de que, em seu entendimento, na racionalidade do tipo de representação que exerce, tal liberdade lhe é assegurada, e tão somente a ela como 'crente' (no sentido de 'crente em Jesus'), dando-lhe possibilidade de falar contra o que quer que seja. Isso porque não é a deputada Silvana, mas "a igreja" que "diz não ao projeto". É a coletividade bem maior, a coletividade dos 'crentes', que em seu discurso busca a retirada.

"Eu estou aqui encomendada literalmente pelos meus pastores, pelos servos de Deus que por muito tempo foram feridos e ofendidos por terem coragem de anunciar o Evangelho", diz ela, ao mesmo tempo legitimando-se a partir da 'fala representativa' da vontade dos pastores (pudessem eles falar era exatamente isso que falariam, é o que se supõe de sua fala) e fazendo ver que é a este segmento que representa.

Tomando a palavra em um aparte concedido por Silvana, o deputado Elmano, depois de informar que havia conversado com outros deputados sobre o projeto, e lembrando sua pertença e a dos outros deputados petistas ao catolicismo (para não serem deslegitimados como não-religiosos), e de lembrar que "a perseguição faz parte da vida daqueles que têm fé”, cita a seguinte situação:

Ontem eu estava conversando com uma pessoa, e eu disse: "Digame uma coisa, já aconteceu com você de ir a um estabelecimento pedir para alugar cadeiras e mesas para fazer um culto e a pessoa se negar a alugar a mesa e as cadeiras porque é para um culto?" Ele disse: "Agorinha. Meses atrás eu fui tentar alugar mesa e cadeiras, e porque era um culto, não queriam me alugar". E um servidor desta Casa estava ouvindo a história e disse: "Comigo aconteceu algo muito parecido. Eu fui a um local e fui alugar mesa e cadeira para o aniversário do meu filho. Eu sou evangélico, deputado, e me perguntaram para quê, se era para um culto". Eu disse: "Mas por quê? Qual a diferença se é para um culto ou para um aniversário, você não aluga mesa e cadeira? - Não! Dependendo do que seja eu vou tomar uma decisão". Diante dessas situações da vida, e é dessas situações concretas... Diante dessa situação o que é que nós estamos propondo? É que esse comerciante que se nega a alugar uma mesa e uma cadeira para um pastor porque é para um culto evangélico, é esse comerciante que tem que ser multado. (Elmano de Freitas). 
Depois de discursar em cima de tal argumentação, lembrando o que seriam perigos reais de se praticar a intolerância religiosa a partir da negação de serviços comerciais a indivíduos que professassem fé diferente daquela professada pelo proprietário de determinado bem ou serviço (como hospedagens em cidades do interior do estado), o deputado concede a palavra à deputada que, longe de concordar com o ideal da não-discriminação com a intolerância, concordará, vendo-a, a partir da perspectiva cristã, pela ótica da perseguição, do martírio e da possibilidade de triunfo após muitas orações, produzindo a conversão do sujeito intolerante (obviamente, isso não deixa de exemplificar a postura etnocêntrica e cristocêntrica da perspectiva adotada pela deputada), o que fica mais explicito quando diz que "o Evangelho do Senhor Jesus não precisa sair e ter uma lei para constranger um comerciante ou um vizinho", como se o projeto, ou qualquer projeto de punição à intolerância religiosa devesse dizer respeito, ou favorecer, apenas a pregação do evangelho. Depois, afirmando que "o crente nem medo de morrer têm porque vai para o céu”, sua incompreensão de que há intolerância com outras religiões, e mais do que isso, de que existem outras religiões, resta evidente.

Então, Deputado Elmano, eu lhe peço, em Nome de Jesus, e eu sei que Vossa Excelência não deseja ser intolerante. Eu acho, inclusive, e acho que Vossa Excelência entendeu essa minha réplica. Qualquer pastor, crente, e aqui nós não podemos defender só o pastor de professar o que ele pensa, é qualquer crente. (Silvana Pereira).

Mesmo dizendo-se alguém que 'gosta do debate', sua ordem é explícita: "Eu quero que Vossa Excelência retire”. Não haveria conversa, não haveria debate parlamentar a se fazer; o projeto não era de interesse da igreja, que parece querer agir com intolerância em relação a outras religiões, e como tal deveria ser retirado.

Em sua resposta, Elmano mostraria firmeza no propósito de fazer o projeto avançar, uma vez que, segundo ele,

A pessoa que tem uma religião, ela não pode ser vítima do preconceito porque ela tem a sua religião. E eu acho que o Estado 
tem que constranger, a pessoa tem que estar obrigada a respeitar a religião de outro. Agora é obrigada não no sentido da discussão religiosa. (Elmano de Freitas).

Tentando elaborar uma formulação a partir da ideia de uma pirâmide de direitos, que teria como ápice a Constituição Federal garantindo a liberdade de crença, na qual ela acreditava estar a liberdade de atacar aquilo que não seria pertinente à crença professada, a deputada é corrigida por seu colega que lembra o fato de que o direito seria "de acreditar", "não de discriminar outra pessoa porque ele tem outra religião". Um debate, pois, muito interessante se instalara ali: o que comporta a liberdade de crença; mas, tal debate, por ter como um de seus atores alguém comprometido com a defesa de sua crença, não avançava em termos de produção de um consenso democrático. Silvana conclui que um evangélico não alugar seus bens a um sujeito de outra religião não seria discriminação "se ele entende que ele está favorecendo a outra religião”.

Neste momento, Elmano lembra à Silvana que havia embates entre católicos e evangélicos e que tais grupos podem produzir, e de fato produzem, discriminações e intolerâncias dentro da própria cristandade. Apesar disso, Silvana negaria a possibilidade de tais atos e, por duas vezes, lembrou ao deputado que suas alegações, e a própria justificativa do projeto, diz respeito às 'religiões afrodescentes'. É nesse momento, pois, que a deputada deixa entrever qual a verdadeira razão de sua oposição ao texto: ele taxaria como crime de intolerância os discursos proferidos contra tais religiões nas igrejas evangélicas, inclusive a clara afirmação de que 'levam ao inferno', como dito anteriormente. Uma lei que proibisse a única forma de relação com estas religiões, ao que parece, seria um golpe mortal nas 'igrejas'.

Isso ficou ainda mais claro quando a deputada passou a falar sobre as religiões de matriz africana, mas o fez tão somente para ressaltar a possibilidade de relação com o cristianismo, sendo a conversão a este a única coisa a se esperar: 
A minha mãe cantava e um maconheiro tocava. Era vizinho o centro de Candomblé. Era. Ele tocava a princípio para minha mamãe parar de cantar. Ele tocava, tocava, toda vida que a mamãe começava a cantar. "Tira o meu povo do Egito, fala o grande Deus de Daniel", ele começava a tocar. Toda tarde, toda tarde. Até que a mamãe disse: "Salomé". "Salomé por que você não para de cantar? Eu fico tocando para você parar de cantar e você canta é mais? Meus meninos ficam tocando. Você está implicando com a gente?" A mamãe disse: "Não, não. Meu querido eu cantava na igreja e não tinha ritmo, agora eu vou cantar na igreja e tenho ritmo porque os seus tambores me dão ritmo". Sabe o que aconteceu com aquele homem? Ele ficou muito amigo da mamãe, aceitou o Evangelho e morreu sendo diácono da Igreja Assembleia de Deus. A tolerância entre as pessoas. Não precisamos de lei para sufocar a crença. E aqui eu digo da minha fé e digo a respeito de quem acredita diferente nas religiões afrodescendentes. (Silvana Pereira).

Observe que a ideia de tolerância parece significar para a deputada o tempo de espera de sua mãe para a conversão do vizinho, 'maconheiro' e adepto do 'candomblé'. Passada toda a explicação do deputado Elmano, com argumentos que iam da Sociologia à Legislação, a deputada se disse "mais do que convencida que o que me fez vir à Tribuna desta Casa, o sentimento do povo contra esse Projeto, se reafirma, cresce". Não havia razão para esperar ou debater/parlamentar: havia que se fazer a igreja 'levantar'.

Encerrado o discurso de Silvana, chegara o momento do deputado Apóstolo Luiz Henrique discursar. Como sempre faz, começou com a leitura de um texto bíblico, e saudando "a todos com a paz do senhor Jesus". Declarando a si mesmo e à Silvana como "enviados por Deus a esta Casa e iluminados pelo Espírito Santo”, "com a responsabilidade de defender o cristianismo", não nega que seu objetivo, assim como o de sua colega, é o de "fazer com que nenhum projeto desse venha a ferir a igreja, venha a ferir realmente o evangelho". Eis sua compreensão de representação, do que representa e, portanto, de como identifica os projetos, e seus autores, que venham a ser por eles interpretados como 'feridas ao evangelho'. 
Suas declarações durante seu discurso dão mostras de sua total incompreensão, ou da reformulação na ideia de representação que sua crença opera: ao dizer que "se o nosso Jesus tivesse deixado na Bíblia, Dra. Silvana, que nós tínhamos que entrar com uma lei dessa forma, nós entraríamos", mistura plano espiritual com plano temporal, legitimidade da Constituição com imperativo do texto sagrado, obediência à Constituição e ao processo parlamentar com mensagem profética; depois, citando um trecho de Mateus 5, o discurso das bem-aventuranças, produz uma ideia de que, por aquele projeto, produzia-se uma 'perseguição aos cristãos'. Depois disso, faz a seguinte declaração, que mesmo sendo longa, nos importa transcrevê-la por completo por julgarmos de suma importância para a compreensão:

Olha o que é que acontece aqui Deputado Elmano, Dra. Silvana só para concluir [...] Romanos Capítulo 1 eu vou fazer uso do mesmo texto que eu fiz no dia aqui daquele embate. Romanos 1 , versículo 22 diz assim: "Dizendo-se sábios tornaram-se loucos e mudaram a glória do Deus incorruptível em semelhança da imagem do homem corruptível, e de aves, e de quadrúpedes e de répteis, pelo que também Deus os entregou as concupiscências do seu coração a imundícia." Vou repetir de novo o que está escrito na bíblia: "A imundícia, para desonrarem o seu corpo entre si, pois mudaram a verdade de Deus em mentira e honraram e serviram mais a criatura do que o Criador que é bendita eternamente, amém. Deus os abandonou as paixões infames, porque até as suas mulheres mudaram o uso natural no contrário a natureza, semelhantemente também os homens, deixando o uso natural da mulher se inflamaram em sua sensualidade um para com os outros, homem com homem cometendo torpeza e recebendo em si mesmo a recompensa que convinha ao seu erro. E, como eles não se importaram de ter conhecimento de Deus, assim Deus os entregou a um sentimento perverso para fazerem coisas que não convém."

Isso daqui está na Bíblia, Dra. Silvana, é o que nós defendemos, é o que nós pregamos, é o que eu falo aqui, Audic, porque está na Bíblia, e é o que qualquer dono de empresa, de estabelecimento comercial pode falar, ok?

[...]

Porque qualquer comerciante Dra. Silvana, qualquer pessoa poderia fazer o uso do mesmo texto que eu usei aqui, Deputado Walter, 
e ele entrar nessa lei como a pessoa que está discriminando outra por causa da religião. Então vai dizer assim: "o dono da empresa tal é homofóbico porque está usando um texto da Bíblia, está falando aqui que essa pessoa..." A Bíblia fala que eles vão ser condenados, eles não vão herdar o reino dos céus, a Bíblia fala. Então, se o empresário, se o comerciante falar isso ele vai ser o que Deputado Elmano? Ele vai ser preso, ele vai ser multado? (Apóstolo Luiz Henrique).

Estando na Bíblia, não se pode ter como ato de intolerância e, mais do que isso, está o crente livre para o fazer. Não há regras de convivência democrática a reger as relações entre os indivíduos, produzindo harmonia e concórdia social, ou mesmo convivência democrática: a Bíblia ordena uma série de práticas que, mesmo que discriminem, legitimam sujeitos no espaço social. Eis a argumentação. Para ser mais exato, o deputado diz: "o que eu defendo é a Bíblia". Em seguida, sua tese é ratificada pela deputada Silvana que, retomando a palavra, dirige-se a Elmano nos seguintes termos:

O projeto de Vossa Excelência é uma tentativa, realmente, agora eu sei por que os pastores estão tão aflitos, realmente é uma tentativa de silenciar, unir e obrigar a se conduzir de forma como uma pessoa não acredita fazendo o Estado punir essa pessoa. [...] A Bíblia é o nosso regimento, a nossa condução maior (Silvana Pereira).

Entre discursos e apartes, Elmano se mostrava como mais convencido de que seu projeto tinha razão de ser, de que haviam sujeitos, e alguns deles estavam ali diante dele, dispostos a praticar a intolerância em nome de sua fé. "A senhora está me dando argumento para o meu projeto”, disse ele à Silvana. Em seus apartes concedidos, sobretudo a deputados religiosos (como o católico Walter Cavalcante [MDB] e o evangélico da IURD, David Durand (Republicanos), a deputada viu a possibilidade de haver, no Plenário, 'guerreiros' prontos para 'derrubar' o projeto. Contudo, o primeiro atestou a capacidade parlamentar e dialogal de Elmano e, mesmo dizendo ter recebido várias ligações de membros da igreja, dispunha-se a "melhorar o projeto", não a sufocar sua discussão como intentavam seus dois outros colegas; por 
sua vez, o segundo, dizendo ter compreendido "perfeitamente o que o Deputado Elmano Freitas traz aqui no projeto" e até concordando "plenamente na questão de combater a discriminação que, muitas vezes, há na questão religiosa”, se dispunha, também, a entrar no debate com o projeto, apresentando outras ideias a ele, e afirmando que "nós teremos a conclusão de um projeto, que vai realmente garantir o combate à discriminação, inclusive religiosa”. Assim, nenhum dos dois reproduzia a mesma significação dada por Silvana ao projeto; pelo contrário, viam nele a possibilidade de se discutir a problemática da intolerância e da discriminação ${ }^{10}$.

Em suas alegações finais, a deputada disse:

Eu quero derrubar o projeto, eu quero que o projeto seja retirado, até porque, para mim, o projeto é um embuste, o projeto realmente quer perseguir... Eu estou perseguindo ele, eu não estou perseguindo o Deputado Elmano Freitas, eu estou atacando e perseguindo a ideia do Deputado Elmano Freitas de querer multar as pessoas que, dentro dos seus estabelecimentos comerciais ou de pensamento, ou dentro da Igreja, ou fora da Igreja, defendam os seus princípios inegociáveis. Para mim, a cruz é o caminho, eu me rendo à cruz, ao que Jesus ensinou (Silvana Pereira).

$\mathrm{Na}$ oportunidade em que retomou a palavra, Apóstolo Luiz Henrique aproveitou seu tempo para ler passagens bíblicas em que, segundo ele, haveria a condenação da homossexualidade e ponderou sobre o que poderia acontecer a comerciantes que se negassem a alugar imóveis por conta dela, ou mesmo de empresários que demitissem, por quaisquer motivos, seus funcionários homossexuais e pudessem vir a ser penalizados. Feito isso, também expôs argumentos que atingiam praticantes de religiões afro-brasileiras:

Parlamentares acreditem ou não, mas existem demônios, existem entidades do mal que são invocadas. Existem entidades que são invocadas por supostas Religiões, supostos sacerdotes, que invocam entidades e essas entidades são pagas com sacrifício. Com sacrifício de sangue derramado. Sangue de animais, ok? E a Bíblia fala e desde os tempos antigos fala. Mas é uma Religião. Eles estão invocando espíritos; eles estão invocando entidades, que, na nossa Bíblia, 
vemos que é demônio; que leva as pessoas a beberem, a fumarem, a matarem, se prostituírem e nós lutamos contra isso. Agora um empresário, um comerciante vai defender a sua fé, vai defender aquilo que é contra o Evangelho, que é contra a santidade, que é contra as ordenações de Deus e aí ele vai ser o que? Multado por discriminação religiosa? O próprio senhor Jesus disse: "bem aventurados sereis" (Apóstolo Luiz Henrique).

Não se trataria, pois, de considerar religiões de matriz africana como 'religiões', portadoras do direito constitucional da liberdade de crença; o filtro sobre o qual se deve olhar para elas, segundo o entendimento do deputado, é tão somente o da oposição espiritual do cristianismo por ele professado a tais crenças; uma relação, pois, de oposição e de 'combate', combate 'espiritual'. Até que ponto tal concepção não expressa, em grande medida, as representações que sobre elas circulam no cotidiano de muitas igrejas cristãs? Por certo, o discurso do deputado é legitimado e legitimador desse cotidiano, atuando como legítimo representante de um conjunto de crenças, como definiu Young. Interpelando-se a si mesmo sob tal condição, afirma estar ali falando "pelo povo cristão, por que foi esse povo que me colocou aqui dentro", fazendo-se observar como um representante das crenças cristãs, acusando as religiões de matrizes africanas de culto dos demônios, e dos interesses dos cristãos, de verem os adeptos de tais religiões os mais acuados, e sem direitos, que fosse possível. Depois de seu pronunciamento, o deputado foi às suas redes sociais e postou um texto comentando sua posição acerca do projeto:

Nesta manhã levamos nosso pronunciamento ao plenário da Assembleia Legislativa. Somos contrários a tudo o que venha contra a liberdade de expressão da nossa fé. O projeto de Lei 578/2019 proposto pelos Deputados petistas Elmano Freitas, Acrísio Sena, Fernando Santana e Moisés Brás está longe de ser uma proteção a liberdade religiosa (até porque a Constituição Federal já nos garante essa liberdade de consciência e de crença), mas o PL cria penalidades para casos de 'discriminação por motivo religioso'. O projeto é completamente desnecessário e mais que isso, é perigoso na prática. Garanto ao povo cristão que seremos resistência na Casa do Povo e afirmo, vamos lutar para retirar o texto de pauta. 
Tudo por amor a Deus, por amor ao próximo e para a Glória de Deus! \#politica \#apluizhenrique uizhenrique \#deputadoestadual \#ceara (Fonte: https://www.facebook.com/apostololuizhenriqueoficial/photos/a.167451703795238/573445316529206).

Apesar de todo o desvio operado por ele e por Silvana, no que diz respeito à argumentação racional, laica, constitucional e parlamentar do que se estava discutindo, Elmano de Freitas, intentando ponderar no campo do direito e da análise das complexas relações que o tema envolve, prosseguiria afirmando que, como parlamentar, era seu dever discutir dentro das normas constitucionais, convidando seus interlocutores a lerem devidamente o que dizia o texto do projeto, chegando a argumentar, no intuito de sensibilizar, que mesmo 'crentes' podem ser prejudicados ao serem alvo de atitudes de discriminação por questões religiosas. Também como Silvana, Henrique responderia que a justificativa do projeto falava das 'religiões afro'. Esse, pois, era um significante que operava a razão de ser da mobilização em contrário: como seria possível a tais lideranças prosseguir em sua fé sem falar mal, apregoar o inferno como destino dos praticantes de tais religiões sem, ao mesmo tempo, incorrer em práticas discriminatórias e serem, por isso, denunciados e multados?

Mesmo argumentando que o texto não se aplicaria à "atos de manifestação de religião, opinião, ideias, convicção, sozinho ou em comum, tanto em público como em privado”, e mesmo por não saber explicar ao certo o que seriam tais atos e como não se aplicaria o texto da lei a eles, o deputado não conseguiu produzir entre seus pares um consenso. Duas semanas depois, em 07 de novembro, o projeto seria retirado de pauta a pedido do próprio Elmano. Segundo disse durante seu discurso, "depois de ter ouvido o Pastor Paixão", que é presidente da Ordem dos Ministros do Ceará (OMERCE) e ligado à deputada Silvana. Algo, porém, merece ser destacado acerca dessa retirada.

Conforme as próprias palavras da deputada, "costurou-se" um acordo para que ela pudesse retirar um projeto de sua autoria, que versava sobre a penalidade a autores de atos de vilipendio a símbo- 
los religiosos, em troca da retirada do projeto dos petistas. $\mathrm{O}$ jogo parlamentar, bastante mundano e prosaico, em ação. Jogo este que não funcionou quando um projeto que era do interesse de sua igreja estava em questão. Por isso, como ela mesma afirma, o projeto com relação às imagens não era "prioridade para minha igreja esse projeto, serviu como uma arma de negociação" ${ }^{11}$. Uma boa entendedora, pois, do jogo parlamentar, mesmo que apenas quando este contempla seus interesses. "A política é a arte de você se fazer ouvir. A minha função não é apenas fazer barulho, é fazer acontecer. Me sinto útil em ver a retirada do projeto do PT", disse ela.

Elmano, por sua, vez, declarou ter visto "incompreensões" em torno do projeto. Ao que nos parece, com bastante ingenuidade, observava que ao retirar os dois projetos, "você se desarma para preconceitos, se desarma de opiniões pré-formadas e você senta, coloca os problemas que nós temos na convivência religiosa”. Enquanto sua colega punha o claro desacordo religioso com a possibilidade da não-intolerância com práticas de outras religiões, ele enxergava possibilidade de diálogo e consenso em torno de um respeito que, a julgar pelas declarações dos opositores, não teria condições de se produzir. Muitos limites se põem, pois, à democracia, à convivência e à produção de consensos quando o jogo político é estruturado por elementos que lhe são estranhos, ou exteriores, como os componentes de uma fé. O que trará à democracia o aprofundamento de representação política calcada em interesses postos a partir de tais elementos?

\section{Considerações finais}

Estabelecemos como principal objetivo deste texto responder à seguinte questão: que usos da ideia de liberdade religiosa são feitos por parlamentares religiosos e que lugar tais usos conferem a religiões minoritárias? Para respondê-la, tomamos como corpus de posicionamentos de deputados evangélicos em relação a um projeto de lei que versava sobre a punição de crimes de intolerância religiosa. Estávamos em busca, na verdade, de elaborar uma reflexão sobre as relações entre 
religião e política institucional tal como se tem observado no cenário político contemporâneo.

Quando se debruçou sobre isso, Chantal Mouffe (2000, 2013) reconheceu que a religião desempenha importante tarefa na formação da identidade pessoal, o que traz consequências diversas para a politica, sobretudo em sociedades pluralizadas, com um conjunto de valores mais diversificado, e de como se daria a atuação política de religiosos. Embora reconheça a legitimidade das empreitadas religiosas em busca de representação política como aprofundamento da própria democracia, Mouffe pondera que tal direito democrático à representação não "permitiria o reconhecimento legal de demandas que poriam em questão a própria base da ordem constitucional, e que poderiam abolir, por exemplo, a separação entre Igreja e Estado" (2006:26). Em outras palavras, projetos de lei apresentados e que trariam prejuízos à devida separação entre os entes, 'contaminando' religiosamente o Estado, deveriam ser freados pelo mesmo mecanismo constitucional que permite a representação de segmentos religiosos. O Estado não seria, assim veículo de propagação legal de valores religiosos.

Pensando, pois, com Mouffe, não temos observado essa pluralidade religiosa, na forma de valores, ser observada nem no funcionamento do Estado em suas várias modalidades, tampouco a empreitada de imposição valorativa de atores religiosos cristãos no campo político ser freada por mecanismos institucionais; em vez isso, o que se observa, tomando inclusive o exemplo dos parlamentares aqui considerados, é um avanço cada vez mais corrosivo de pautas, depois transformadas em decisões políticas, de viés conservador que põem em xeque a própria concessão de direitos, orgulhando-se tais sujeitos das garantias de tratamento diferenciado às pautas que dizem respeito aos valores da 'maioria cristã' da sociedade brasileira.

Por isso, concordamos com a análise de Carranza (2020) acerca de uma certa cooperação de atores religiosos aos processos de corrosão democrática e de polarização social, acompanhados do ultracon- 
servadorismo, que se tem observado nos últimos anos em diversas organizações sociais, com destaque para o Brasil. Uma crise democrática mais ampla tem proporcionado a ascensão de personas políticas, ou grupos, que, postando-se como de 'fora' do sistema, poderiam salvá-lo, por meio de uma reconstrução de valores que estariam deteriorados e, por isso mesmo, estariam a destruir o próprio corpo da nação. A crise é potencializada pela conjunção entre a retórica do 'inimigo', advinda da tradição agônica (Mouffe 2000 e 2013) e da desconexão entre os enunciados e as verdades factuais, bem como de suas condições de verificabilidade e conversação coletiva que produzem consenso (situação de pós-verdade). Os enunciados passam a girar em torno de si, mas, simultaneamente movidos a likes e engajamentos via redes sociais, o que causa a flutuação na semântica de tópicos históricos como 'liberdade de crença' e 'perseguição religiosa'; ora movidos por puros interesses corporativos (busca da própria sobrevivência individual e ou do grupamento), ora movidos por ressentimentos religiosos acumulados contra o Mundo Moderno e suas configurações (família, sociedade e cultura), ora por conta do puro grotesco. Essas novas conjunções e convergências abalam o alicerce da estrutura representativo-parlamentar liberal no Estado laico em seu âmago. Assim, religiosos entrariam como as apostas de salvação dessa destruição.

Se a atuação política de religiosos tem tomado o rumo de cada vez mais fortalecer a presença da religião cristã na esfera pública, com intento de garantir-lhe a posição de guia e de ator hegemônico de que já dispõe na vida social, transferindo-a para o Estado; é de se esperar que, a médio prazo, a natureza representativa e plural da democracia seja cada vez mais posta em dúvida e deslegitimada, frente a um Parlamento que cada vez mais tende a se responsabilizar pela (re)construção de uma 'sociedade cristã' (Eliot 2016). 


\section{Notas:}

1 Tendemos, de forma um tanto equivocada, a separar economia e política, liberalismo político de liberalismo econômico. Mostram essa inseparabilidade, os últimos tempos de Sindemia de Covid-19, novo termo da epidemiologia para caracterizar a indissociabilidade entre doenças como a Covid-19 e as questões sociais, arquitetônico-urbanísticas, sanitárias econômicas culturais e políticas. É algo bem similar à tese de que o vírus, todo ele, quando entra nas sociedades e histórias humanas, se torna político.

2 Conforme: https://www.cmfor.ce.gov.br/2019/10/22/vereador-se-manifestacontra-projeto-que-preve-penalidade-para-atos-de-discriminacao-religiosa/.

3 Sendo exatamente por isso também o meio pelo qual o religioso se torna político.

4 Essa passagem bíblica, dentre outras, em especial as do antigo testamento, completamente encharcadas de metáforas de guerra, alimenta a retórica evangélica brasileira, mas não somente, há muito tempo. O relato mítico do Livro de Juízes é muito interessante e se insere no contexto da narrativa épica de consolidação das tribos israelitas em um Estado-Nação em meio a um ambiente hostil e cheio de inimigos. $\mathrm{O}$ mito narra como Deus, YẢWHE, fala ao juiz eleito por ele, Gideão, para selecionar de 22 mil homens. Por uma série de provas, ficam apenas 300 homens: os que desceram ao riacho e lamberam a água com as mãos. Esse grupo pequeno lutou contra um exército de milhares, mas que será derrotado por artimanhas boladas pelo líder.

5 Veja-se a luta pelo monopólio da representação política no campo evangélico. Não é possível no âmbito deste texto abordar as movimentações dos grupos religiosas a partir de patuás liberais-esquerdo-anarquistas. Assinalamos que nas eleições municipais de 2020, surgiram uma centena de candidaturas de evangélicos e católicos identificados com pautas não-conservadoras e reacionários foi o mais elevado dos últimos a os. Disponível em: https://noticias.uol.com.br/eleicoes/2020/09/09/ contra-neopentecostais-1-bancada-evangelica-de-esquerda-se-lanca-em-2020.htm. Acesso em 11/01/2021.

6 Elmano de Freitas, Acrísio Sena, Moisés Braz e Fernando Santana. Destes, destaque-se que apenas Elmano envolveu-se abertamente com as discussões em torno do projeto quando das polêmicas em torno dele.

7 O texto do Projeto pode ser acessado em: https://www2.al.ce.gov.br/legislativo/tramit2019/pl578_19.htm.

8 Disponivel em: https://www.cmfor.ce.gov.br/2019/10/22/vereador-se-manifesta-contra-projeto-que-preve-penalidade-para-atos-de-discriminacao-religiosa/. Acesso em 13/01/2021.

9 Todas as falas foram retiradas do arquivo de notas taquigráficas da ALCE solicitada por um dos autores deste texto.

10 Por certo, no caso de Durand, membro da IURD, a longa experiência de intolerância à sua instituição, ainda persistente em alguns lugares, inclusive dentro do próprio universo evangélico, o tenha feito colaborar com a possibilidade de discussão em torno da temática. Por muitos momentos, a IURD adotou/adota a simbólica da 'minoria religiosa' para demarcar sua presença no campo religioso e na 
sociedade brasileira, dado o acúmulo de experiências dentro desta seara. Sobre isso ver Camurça (2020).

11 Sobre isso, ver: https://blogdoedisonsilva.com.br/2019/11/apos-pressao-de-evangelicos-deputados-do-pt-retiram-projeto-que-penaliza-a-pratica-de-discriminacao -por-motivo-religioso/. Acesso em 10/12/2020.

\section{Documentos:}

BÍBLIA. 2009. Juízes 7-9. (www.biblegateway.com/ passage/?search=Ju\%C3\%ADzes\%207-9\&version=ARC; acesso em $11 / 01 / 21)$.

\section{Referências:}

ALENCAR, Gustavo. 2019 "Grupos protestantes e engajamento social: uma análise dos discursos e ações de coletivos evangélicos progressistas.” Religião B Sociedade, 39(3):173-196.

ALMEIDA, Débora. 2013. "A relação contingente entre representação e legitimidade democrática sob a perspectiva da sociedade civil.” Revista Brasileira de Ciências Sociais, 28(82):45-65.

ALMEIDA, Ronaldo. 2017. "A onda quebrada: evangélicos e conservadorismo." Cadernos Pagu, 50:175-190.

BUCCI, Eugênio. 2019. Existe democracia sem verdade factual? Barueri: Estação das Letras e Cores.

BURITY, J. \& MACHADO, M. D. (eds.). 2006. Os votos de Deus: evangélicos, política e eleições no Brasil. Recife: Editora Massangana.

CAMURÇA, Marcelo. 2020. "Igreja Universal do Reino de Deus: entre o 'plano de poder' e a lógica de minoria perseguida." Religião E⿱ Sociedade, 40(1):43-65.

CARRANZA, Brenda. 2020. "Erosão das democracias latino-americanas: a ascensão política dos cristãos”. Ciencias Sociales y Religión, 22:1-17.

CUNHA, Christina. 2015. Oração de traficante: uma etnografia. Rio de Janeiro: Garamond.

FONSECA, Alexandre. 2002. Secularização, pluralismo religioso e democracia no Brasil: um estudo sobre a participação dos principais atores evangélicos na política (19982001). Tese de Doutorado. São Paulo: USP.

FRESTON, Paul. 1993. Os Protestantes e a Politica no Brasil. Tese de Doutorado. Campinas: UNICAMP.

LACERDA, Marina. 2019. O novo conservadorismo brasileiro: de Reagan a Bolsonaro. Porto Alegre: Editora Zouk. 
MACHADO, Carly. 2017. "The church helps the UPP, the UPP helps the church: pacification apparatus, religion and boundary formation in Rio de Janeiro's urban peripheries." Vibrant, 14: 75-90.

. 2014. "Pentecostalismo e o sofrimento do (ex-)bandido: testemunhos, mediações, modos de subjetivação e projetos de cidadania nas periferias." Horizontes Antropológicos, 20:153̈-180.

MANIN, B., PRZERWORSKI, A. \& STOKES, S. 2006. "Eleições e representação." Revista Lua Nova, 67:105-138.

MARIANO, Ricardo. 2011. "Laicidade à brasileira: católicos, pentecostais e laicos em disputa na esfera pública." Civitas, 11(2):238-258.

MARIANO, R. \& ORO, A. 2013. Introdução ao dossiê Religião, política, espaço público e laicidade no Brasil. Revista Cultura y Religion, 7(2):4-12.

MEZZOMO, F., SILVA, L. \& PÁTARO, C. 2021. "Pela 'família tradicional': campanha de candidatos evangélicos para a ALEP nas eleições de 2018”. Revista Brasileira de História das Religiões, 13:13-41.

MONTERO, Paula. 2009. "Secularização e espaço público: a reinvenção do pluralismo religioso no Brasil." Revista etnográfica, 13(1):7-16.

MOUFFE, Chantal. 1993. The Return of the Political. London: Verso.

1999. "Carl Schmitt and the Paradox of Liberal Democracy". In MOUFFE, C. (ed.): The Challenge of Carl Schmitt, pp. 38-53. London: Verso. . 2000. The Democratic Paradox. London: Verso. . 2013. Agonistics: Thinking the World Politically. London: Verso.

ORO, Ari P. 1996. Avanço Pentecostal e Reação Católica. Rio de Janeiro: Vozes.

PIERUCCI, Antônio. 1989. "Representantes de Deus em Brasília: a bancada evangélica na Constituinte", Ciências Sociais Hoje, 1:104-132

PITKIN, Hanna. 1967. The concept of representation. Berkeley: University of California Press.

QUADROS, M. \& MADEIRA, R. 2018. "Fim da direita envergonhada? Atuação da bancada evangélica e da bancada da bala e os caminhos da representação do conservadorismo no Brasil." Opinião Pública, 24(3):486-522.

SILVA, Luís G. 2019. "O processo de representação política construído pelas igrejas pentecostais (1985-2016).” Latino Ë Mérica, 69(2):127-159.

URBINATI, Nadia. 2006. "O que torna a representação democrática?". Revista Lua Nova, 67:191-228.

YOUNG, Iris M. 2006. "Representação política, identidade e minorias." Revista Lua Nova, 67:139-190.

VAGGIONE, Juan. 2017. "La Iglesia Católica frente a la política sexual: la configuración de una ciudadanía religiosa." Cadernos Pagu, 50:1-35.

WAGNER, Roy. 2017. Símbolos que representam a si mesmos. São Paulo: Editora Unesp.

WITTGENSTEIN, Ludwig. 2005. Investigações filosóficas. Petrópolis: Vozes. 


\title{
'The Bible Is our Rules': parliamentary debate, freedom of belief and representative liberal democracy
}

\begin{abstract}
Questioning the reason for legislating on crimes of religious intolerance, we aim to analyze the relationship between religion and politics in contemporary Brazil from the uses of the idea of freedom of belief by religious parliamentarians. The processing of Bill 578/2019, in the Legislative Assembly of Ceará, authored by PT deputies and which dealt with the punishment of crimes of religious intolerance, was impeded by evangelical deputies for seeing 'threats to the Church of Jesus', under the 'freedom of belief' argument. Based on qualitative methodologies partial bibliographic review, discursive analysis and the concepts 'religious citizenship' and 'agonistic democracy', we will investigate this hypothesis: the deputies oppose a 'wall' against projects seen as a 'threat to faith', legitimizing, within the limits of representative democracy, the moralreligious code. It is intended, therefore, to understand the limits placed on the secularity of the State by the performance of parliamentarians who make the defense of the interests of their institutions the raison d'être of their mandates.
\end{abstract}

Keywords: Parliamentary representation, Freedom of belief, Religious intolerance, Religious citizenship.

Recebido em abril de 2021. Aprovado em outubro de 2021. 